\title{
Burden Sharing and Dublin Rules - Challenges of Relocation of Asylum Seekers
}

\begin{abstract}
By Lehte Roots*
Mediterranean route has become the most used irregular migration route to access the borders of European Union. Dublin regulation has set up principles that a country which has allowed the immigrant to access its territory either by giving a visa or giving an opportunity to cross the border is responsible for asylum application and the processing procedure of this application. These rules have put an enormous pressure to the EU countries that are at the Mediterranean basin to deal with hundreds of thousands of immigrants. At the same time EU is developing its migration legislation and practice by changing the current directives. The role of the Court of Justice in this development should also not be under diminished. From one point of view EU is a union where principles of solidarity and burden sharing should be the primary concern, the practice though shows that the initiatives of relocation of asylum seekers and refugees is not taken by some EU member states as a possibility to contribute to these principles, but as a threat to their sovereignty. This paper is discussing the further opportunities and chances to develop the EU migration law and practice in order to facilitate the reception of persons arriving to EU borders by burden sharing.
\end{abstract}

Keywords: Irregular migration, relocation, resettlement, Dublin rules, burden sharing

\section{Introduction}

"We all recognized that there are no easy solutions and that we can only
manage this challenge by working together, in a spirit of solidarity and
responsibility. In the meantime, we have all to uphold, apply and
implement our existing rules, including the Dublin regulation and the Schengen acquis." (Informal meeting. . . 2015)

The current Migration flows crisis is usually associated with forced and irregular migration. Forced migration is a term that is used to describe a movement that is driven by an element of compulsion, for example threat to life and livelihood arising from either natural or man-made causes. Irregular migration is a concept used to define movement that takes place outside of the regulatory norms of the sending, transit and receiving countries.

We should not forget that also irregular migrants have human rights and these rights should be respected. Protection of human rights is important principles of European Union and EU has a commitment to do everything in their power to guarantee the existence of these rights. ${ }^{2}$

Until recently, it seemed like the European Union's common asylum system was functioning and all the nation states were in agreement with the set rules and

* LL.B.; M.P.M.; M. Research; Ph.D., Associate Professor, Chair of Public Law, Tallinn Law School, Faculty of Social Sciences, Tallinn University of Technology, Tallinn, Estonia.

${ }^{1}$ International Organisation for Migration, (2015).

${ }^{2}$ Art 6 of the TEU 
regulations. However, the sheer volume of people currently arriving to the EU by using illegal methods for border crossings, whether it is in search of international protection or just for a better life, has made it clear that there is no common understanding on how to meet up with the international expectation to guarantee the protection of human rights without endangering the wellbeing of the state itself or the people. The fact that the EU has not been able to deal with the crisis decisively has led the Union into a solidarity crisis in general.

The right to seek asylum is a fundamental human right. There are many international law instruments that have incorporated this right: starting from the Universal Declaration of Human Rights to the EU's Common Asylum System as an integral whole.

The most important source of international protection of refugees is the Universal Declaration of Human Rights and 1951 Refugee Convention. According to the Universal Declaration of Human Rights Article 14, paragraph 1 "Everyone has the right to seek and to enjoy in other countries asylum from persecution". 3 This provision gives people the right for protection from other countries and morally compels states that have vowed to respect human rights, to provide it.

However, the reality is that there is no cohesion amongst states in defining human rights nor are their capabilities or desires to protect them at the same level. States vary enormously between one another in the terms of fundamental values, economic and political circumstances. Nevertheless, the international community has decided that no human being should endure inhumane conditions just because of the geographical location where he or she has born in. As a result, human rights should be protected by every member of the international community and if one fails to fulfil this obligation, no matter the reasons behind the failure, then others shall step in and offer it if the person at hand has asked for it.

Likewise, to defining human rights, there was no coherence between states in determining who a refugee actually is? In order to help states, define them and the minimum rights that they are entitled to, the 1951 Refugee Convention was created by the United Nations. This document was a post Second World War instrument that was created in order to help states deal with displaced people. The document was originally limited, only regulating people who fled their origin states from events that happened before the 1 of January 1951 within Europe. The 1967 Protocol to the Convention removed those limitations, thus making the Convention universally usable. ${ }^{4}$

The most important article of the Convention in the context of this analysis is the one that has defined who a refugee is. According to the Convention's article 1A (2) a refugee is a person who is outside his or her country and has a factual reason to fear persecution because of his or her race, religion, nationality, membership of a particular social group or political opinion and is unable to avail her- or himself to the protection of that country. ${ }^{5}$ There are 142 states that have ratified both the 1951 Convention and it`s 1967 Protocol. ${ }^{6}$ This means that the

\footnotetext{
${ }^{3}$ Universal Declaration of Human Rights (1948).

${ }^{4}$ Achiron (2001) at 8.

${ }^{5}$ The 1951 Geneva Convention relating to the status of Refugees and it's 1967 NY protocol.

${ }^{6}$ States Parties to the 1951 Convention relating to the Status of Refugees and the 1967 Protocol.
} 
majority of existing countries have agreed upon the same criterions to what a person's condition, whose application for asylum is being handled, should answer to. However, the Convention itself does not create a joint understanding in what does the "factual fear of persecution" clause actually mean or how should one determine if the fear is indeed factual or not, which in turn leads to different decisions amongst states.

In 2015 the number of asylum seekers within EU doubled and the EU received close to 1.3 million asylum applications. ${ }^{7}$ The top three origin nationalities of all the asylum applicants in 2015 were Syrian (29\%), Afghan (21\%) and Iraqi (10\%) ${ }^{8}$ Even though almost $30 \%$ of 1.3 million seems a very high number at first, then the altogether situation of Syrians is much worse. It is estimated that approximately 9 million Syrians have left their origin country since the civil war started in March 2011. According to the United Nations High Commissioner for Refugees, over 3 million have taken refuge in the neighbouring countries like Turkey, Lebanon, Jordan and Iraq; however most of them are still displaced within Syria itself. 9

The main entry points, for irregular migrants, to Europe are Greece and Italy. In 2015 Greece received 853650 arrivals by sea and only 3713 by land. Italy received 153842 arrivals by sea and 0 by land. However, the highest number of arrivals by land was received by the Bulgarians, almost 32000 people. Spain, Cyprus and Malta are also frequently used as entry points. ${ }^{10}$

Theoretically the EU should have been ready to handle the increase of people entering the Union: joint regulations had been drafted, enforced and Member States have had years of practice in handling asylum claims. It is evident that the common asylum system has actually not functioned because of internal contradictions in the system itself, the incomplete nature of the Unions integration and because of the different interests of Member States. ${ }^{11}$ Those three are the key elements in understanding the reasons why the EU has not been able to act unanimously and decisively.

This article is analysing the EU legislation, political decisions, court cases and scientific articles written about the EU migration law and policy, focusing on burden sharing and Dublin rules. First the Dublin rules are discussed after that the article elaborates on the role of Court of Justice of EU and European Court of Human Rights in alteration of EU migration law and finally EU approach and problematic issues are highlighted at the end.

\section{Dublin Rules}

One of the foundations of the European asylum system, the Dublin regulation, is also an example of the Union's incomplete and superficial nature of the approach to refugees. The nature of the system, that the country where the asylum applicant

\footnotetext{
7 Asylum Statistics. Eurostat. http://ec.europa.eu/eurostat/statistics-explained/index.php/Asylu m_statistics\#Asylum_applicants. (10.11.2016).

${ }^{8}$ Ibid

9 Syrian Refugees. Migration Policy Centre of the European University Institute. http://syrianre fugees.eu/?page_id=10 (20.04.2016)

${ }^{10}$ Ibid

${ }^{11}$ Bagdonas (2015) at 7.
} 
entered is responsibly to handle the asylum claim, is creating inequality amongst Member States because it has always put more pressure and responsibility on the Border States than on anyone else. ${ }^{12}$

At first the system was created to prevent asylum shopping and to shield wealthy EU states from asylum seekers. However, this protection came on the expense of the Border States. For example, the Greek island of Lesbos, that has a native population of 86000 people and a reception capacity of 2800 people, received over 350000 migrants in 2015 . Under those circumstances it is very difficult to ensure the basic living conditions for the migrants, let alone to ensure applying the set out procedure rules. ${ }^{13}$

Thus the Dublin system is making it impossible for the country to be able to handle the situation of mass influx, individually. Furthermore, the state does not only have to take responsibility of the refugees who lodge their asylum claims to them, but also for all the asylum seekers who are physically sent back from other Member States where they have applied for asylum if they entered the EU from another country. The movement of people is tracked by EU's fingerprint database that raises alerts if an asylum seeker has already been entered into the system, meaning that they have entered the EU at another official border. ${ }^{14}$ This is however only the case when the asylum applicant has been registered correctly, without it, it is almost impossible to positively identify where the applicant did actually entered to the EU. The responsibility to handle the claim is at the hands of the state, where the applicant is currently located. Dublin regulation is also making the registration of arrived asylum seekers an undesirable act. As those registered in the first country of entrance generally become burden for that state where they were first registered. There are some exemptions though also to this rule.

It was expected that through eliminating the confusion and conflicting decisions that surfaced when it was realised that the asylum applicant had made applications in different states, the new system would actually increase solidarity between states. In practice it has had a reverse and negative outcome on the EU's solidarity. The reason is as was already stated due to the fact that the entire burden has fallen on the hands of Border States and the other Member States have not been actively participating in any burden sharing mechanisms or compensating inequality. ${ }^{15}$

Another example of the contradiction in the system is the fact that it is quite a large financial burden for states to handle and provide the minimum standards set out in the European rules for asylum applicants. There are very large differences between the financial capacities of Member States, meaning that there are very big differences of financial instruments that a state can use. Theoretically, all asylum applicants are entitled to the same rights, yet in practice the wellbeing of asylum applicants varies enormously. ${ }^{16}$

Ironically the Border States, who have the biggest burden to carry, are the ones who do not have their financial situations under control, i.e. Greece. However, it

\footnotetext{
${ }^{12}$ The Dublin System. European Commission.

${ }^{13}$ Bagdonas (2015) at 9.

${ }^{14}$ Langford (2013) at 225.

${ }^{15}$ Langford (2013) at 225

${ }^{16}$ Bagdonas (2015) at, 12-13
} 
needs to be noted that the international protection model does not take the situation of the receiving country into consideration, because the desire to ensure the protection of human rights, should ideologically be above everything else, and states should be able to finance it.

The different situation of Member States in turn leads to another problem that creates a cycle even inside the EU itself. Because of the differences of the economic situations of Member States and the disparity of the national asylum regimes, it is possible that one EU member state can be held liable for human rights violations of another. ${ }^{17}$ This would however be unacceptable for the EU as a whole, because each Member State should be able to carry and respect all of the main principles of the EU and if not then it is a problem of the Union's core values as a whole. But in doing so, the EU would reduce its legitimacy and undermine its international reputation. ${ }^{18}$ Nevertheless the ECrtHR has made a decision that elaborates on this kind of responsibility. The expectations for the EU are not high only inside the Union, but in the international scene as well. As a result, it is not an option for the European Union not to take action. Since the beginning of this crisis, the EU faced a great challenge due to the inability to maintain some of the existing rules due to their ill-advised nature. As the crisis has evolved through time, the situation has only worsened. If existing rules and regulations do not alleviate but rather deteriorate the situation, the only logical step is to change the set rules. However, it is not easy to radically change rules in the European Union due to self-imposed constraints and disagreements about what and how should actually be changed?

The revised Dublin Regulation contains more specific provisions on detention, as it will be discussed further on. Serious concern is also the rising amount of asylum seekers being detained who are awaiting a Dublin transfer to another EU country; although the Dublin Regulation did not previously have specific provisions on detention, some Member States have nonetheless resorted to using detention in connection with implementing the Dublin rules. In the new Regulation 604/2013 (Dublin III), the sovereignty clause and the humanitarian clause are included in an article dedicated to the 'discretionary clauses'. The Dublin system is to a large extent dependent on the interpretations of these clauses by the ECrtHR and the CJEU that will be discussed later in this article. To date, the judgments by these two courts lead to the conclusion that the protection of the principle of non-refoulement interpreted in the light of the prohibition of torture and inhuman or degrading treatment, and the principle of protection of the family unit, define this discretion to the extent that these clauses become the mechanisms ensuring that these rights are respected in the European system known as Dublin III for assigning responsibility for examining an asylum application.

\section{Role of the CJEU and ECrtHR}

Both courts European Court of Human Rights and the Court of Justice of European Union have been actively taking decisions related to the application of EU migration law and human rights law. Also the EU member states are using the

\footnotetext{
${ }^{17}$ Langford (2013) at 218

${ }^{18}$ Boswell (2000) at 550.
} 
courts to get the opinions on the application of the decisions made by European Union. For example, Visegrad group countries, contested the mandatory quotas in the European Justice Court and the border fence building done by several states. ${ }^{19}$ It shows that the Court has an important role to play, in adjusting the burden and solidarity between the member states.

Another important court is the European Court of Human Rights that has also competence to make decisions that impact the implementation of EU immigration policy and rules. One of the cases related to Greece is also important to be discussed. In the case of M.S.S. v Belgium and Greece ${ }^{20}$, the applicant was an Afghan national who had entered the EU in 2008 through Greece; having had his fingerprints taken there and having been issued an order to leave the country he then travelled through France to Belgium, where he applied for asylum. He was initially placed in a reception centre in Belgium, while the Belgian authorities requested Greece to take the applicant back, pursuant the Dublin Regulation. Applicant was transferred back to Greece. He attempted to leave Greece again with false ID card and was imprisoned again.

After another attempt to leave Greece the Greek authorities allegedly attempted to expel the applicant to Turkey. ${ }^{21}$

The applicant made a claim against Greece to the ECHR based on Article 3 of the Convention (prohibition of torture) because of the conditions of his detention, and on Article 13 (right to effective remedy) because of the deficiencies in the asylum procedure in Greece. He made a claim against Belgium based on the same Articles because Belgium had exposed him to the risks posed to his rights under Article 3 and 13 of the Convention by sending him back to Greece. The Court first found that there is a breach of Article 3 on the part of Greece, for having knowingly let the applicant to live on the streets of Athens. The Court also found a breach of Article 13, as the applicant's asylum claim had, even as the European Court was considering his case, not been decided, which showed significant deficiencies in the Greek authorities' examination of the applicant's asylum claim. As to the actions of the Belgian authorities, the Court found that, in light of all the information available to Belgium on the appalling detention conditions asylum seekers are subjected to in Greece, and on the negligible rate of successful asylum claims in Greece (around $0,1 \%$ at first instance compared to $36 \%$ in Germany for example), the Belgian authorities did in effect breach Article 3 of the Convention by subjecting the applicant to such conditions, when they had a legal possibility under the Dublin Regulation to refrain from transferring him. A breach of Article 13 was also found on the part of the Belgian authorities, as the applicant was unsuccessful in staying the decision to transfer him to Greece because of minor procedural technicalities. ${ }^{22}$ The UNHCR likewise found that the detention conditions in Greece were appalling. ${ }^{23}$

\footnotetext{
${ }^{19}$ Case C-643/15 Slovakia v Council and Case C-647/15, Hungary v Council,

${ }^{20}$ ECrtHR - M.S.S. v Belgium and Greece [GC], Application No. 30696/09

${ }^{21}$ ECrtHR - M.S.S. v Belgium and Greece [GC], Application No. 30696/09, paras 9-53

${ }^{22}$ ECrtHR - M.S.S. v Belgium and Greece [GC], Application No. 30696/09

${ }^{23}$ Mallia (2011) at 117-118
} 
The Court's findings against Belgium for applying the Dublin Regulation, even when it was known that an applicant's rights would most likely not be protected in the receiving state, regardless of that state belonging to the Common European Asylum System, means that EU states can no longer take it for granted that applying the Dublin Regulation will relieve the sending state of any responsibility for the procedure applied to the asylum seeker in the receiving state. This is contrary to the decision reached in K.R.S. v United Kingdom ${ }^{24}$ from 2008 where the Court found that a complaint regarding a return, pursuant the Dublin Regulation, of an asylum seeker to Greece as manifestly ill-founded; in that case the Court found that the inefficiencies of the Greek asylum system should have been taken up by the applicant directly with the Greek authorities, especially regarding the possible violations of EU asylum law by Greece. The difference regarding this case is that M.S.S. had already been sent to Greece and had experienced the poor conditions there, and his claim was against both the sending and the receiving state. Judge Bratza in his dissenting opinion in M.S.S brought out that the Belgian authorities should have been able to rely on K.R.S. v United Kingdom of not being responsible for the applicant's condition, when sending him to Greece. The outcome however leaves somewhat open the question, to what extent a sending state is responsible for ensuring that the recipient state's asylum system is functional, and what is required of a state that plans to affect a Dublin transfer. ${ }^{25}$

It can be argued even that the judgment puts a rather heavy burden on a sending state when applying the Dublin Regulation; membership in the EU and transposition of EU asylum legislation is not sufficient guarantee to safeguard against refoulement in the receiving state, but more steps need to be taken by the sending state to ensure the asylum seeker's rights are protected and respected. The Court even went as far as saying that EU asylum legislation needs to perhaps be revised to better take into account the needs and constraints of particularly Greece and to better take into account present realities. ${ }^{26}$

Despite inadequate detention and asylum conditions in certain Member States, other EU states were unwilling to halt transfers to Greece, and hardly ever used the sovereignty clause of the Dublin Regulation, assuming that belonging to the EU and thus being bound by EU asylum legislation was prima facie evidence of a sufficient level of protection. The Dublin Regulation evidently cannot however function properly if there are such discrepancies in the examination of asylum applications and the conditions asylum seekers are subjected to.

Due to this judgment, and the cited jurisprudence of previous ECrtHR case-law, it can be argued that a state party to the ECHR should not return asylum seekers to such states where their rights under the Convention risked being violated. The European Court of Human Rights (ECrtHR) in its judgment on the case of MSS v Belgium and Greece, and the Court of Justice of the European Union (CJEU) and in

\footnotetext{
${ }^{24}$ ECrtHR - K.R.S. v the United Kingdom, Application no. 32733/08 (decision on admissibility), 2 December 2008.

${ }^{25}$ Clayton (2011) at 759-762

${ }^{26}$ Mallia (2011) at $125-128$
} 
its judgment on $\mathrm{NS}$ and $\mathrm{ME}^{27}$, established an interpretation of the so-called sovereignty clause of Regulation $343 / 2003$ by which its activation became mandatory in certain cases of serious risk of human rights violations. As a result, a regulation that in principle contained a power for states became the guarantee that the system respected the protection of human rights.

\section{Actions taken to resolve the Crisis}

The Council of the European Union has declared seven strategic priorities in order to tackle the migratory pressures that the Member States are under. Those seven priorities include both dealing with the root causes of illegal migration as well as tackling the problems that stem from the Union's Common Asylum System itself. $^{28}$

The actions of the EU have been divided into two categories. The foundations of the strategic priorities plan was created on the 23rd of April in 2015, when the European Council had their first special meeting in order to address the migration crisis. $^{29}$

The leaders of the EU agreed on four priority areas for action:

Firstly, to fight traffickers by disabling the use of vessels by smugglers, increasing cooperation to work against smuggling networks and to offer EU immigration officers help and knowledge to the countries that are unable to control their borders.

Secondly to strengthen the EU's presence at sea by tripling the resources available to the EU-s border mission in the Central Mediterranean. To prevent illegal migration flows by enhancing general cooperation with the countries of origin and transit, with a focus on countries surrounding Libya.

And finally to reinforce internal solidarity and international responsibility, by offering more protection for refugees and setting up a first voluntary pilot project of resettlement all around the EU. ${ }^{30}$

In brief, the actions of the first meeting were mainly focused on finding ways to stop the illegal migration into the EU by targeting the ones that enable the hazardous journeys on the Mediterranean. There was a political call for taking responsibility of the already arrived refugees by creating a relocation program, but the participation in it was voluntary.

A few weeks later on $13^{\text {th }}$ of May 2015, the European Commission published an official European Agenda on Migration ${ }^{31}$. In general, it is a detailed version of the Council's agreed fundamental actions. According to the Agenda, there are again four main components to create an effective EU migration policy, which all fundamentally support the goals set out by the Council. The main specifications of the document were the proposals on how to achieve a strong common asylum

\footnotetext{
${ }^{27}$ Judgment of the Court (Grand Chamber) of 21 December 2011. N. S. (C-411/10) v Secretary of State for the Home Department and M. E. and Others (C-493/10) v Refugee Applications Commissioner and Minister for Justice, Equality and Law Reform

${ }^{28}$ Finding solutions to migratory pressures.

${ }^{29}$ Special Meeting of the European Council 23/04/2015.

${ }^{30}$ Ibid

${ }^{31}$ European Agenda on Migration.
} 
policy? It consists of different actions that need to be conducted in order to tackle the weaknesses exposed by the crisis. One of the first visible weaknesses is the lack of mutual trust between Member States, a result of the continued fragmentation of the implementation of asylum systems. This has had a direct impact on asylum seekers, as well as on the EU's public opinion that sees the system itself fundamentally unfair. In order to create trust, it is therefore necessary to ensure a full and coherent implementation of the Common European Asylum System that is supported by a systematic monitoring process with a purpose to oversee the implementation and application of asylum rules amongst the Member States. In addition, it is necessary to create coherent decisions on asylum applications and to speed up the process of handling the applications by the creation of a joint safe country. ${ }^{32}$

As it has been already stated, the CEAS creates inequality amongst Member States, which in turn creates dissatisfaction and consequently has a negative impact on the European solidarity, as a fundamental principle of the EU.

Another weakness that needs to be addressed is that the EU's return system meant to return irregular migrants or those whose asylum applications are refused, does not function. Instead, it has become one of the incentives of irregular migration. Smuggling networks count on the fact that relatively few return decisions are enforced, for example only about $40 \%$ of return decisions were effectively enforced in $2013 .{ }^{33}$ Even though the topic was acknowledged, the Agenda did not have a specific action plan in order to tackle this weakness.

The fourth and final pillar of the Agenda is the goal to reinforce internal solidarity and responsibility by triggering an emergency response system. The Agenda includes a proposal of a temporary distribution scheme for persons in need of international protection that would distribute the people according to the set out criteria. The redistribution criteria consist of GDP, size of population, unemployment rate and past number of asylum seekers and of resettled refugees. In addition, the Commission also emphasised that it is the EU's duty not only to take responsibility of the people already on the EU soil but to help others in need as well. $^{34}$

The relocation and resettlement schemes were created to divide 40000 places for refugees amongst all Member States. Relocation means moving a refugee from one Member State to another, but resettlement means to move a refugee from a third country to a Member State, thus fulfilling the international expectation to help with the global migration crisis. The total number of relocated people was estimated to be 20000 , as was the number of resettled people. ${ }^{35}$

The distribution key itself is of an interesting nature because it does take the previous experience of the country into account, but not the reasons of the countries lack of experience. As a result, the distribution key does not actually eliminate the fundamental inequality amongst Member States, because the ones that have more experience i.e. have been willing to accept more refugees in the past, are still the ones who are carrying the most weight in tackling this problem. In 2014 Germany

\footnotetext{
${ }^{32}$ Ibid., 12

${ }^{33}$ Ibid., 8

${ }^{34}$ Ibid., 4

${ }^{35}$ Ibid., 19
} 
was the recipient of the largest number of asylum applications, followed by France, Sweden, Italy and the United Kingdom. ${ }^{36}$

In comparison to the Agenda, the first measure package is another step onward for more concrete actions. There were a few major specifications in the document that were new: the relocation scheme would focus on Syrian and Eritrean nationals and who have arrived in either Italy of Greece after 15 April of 2015 or that arrive after the mechanism is launched and the number of recipients doubled and rose up to 40000 people. To help with the financial burden of accepting people, it was also proposed that the Member States will receive 6000. - EUR for each person relocated on their territory. ${ }^{37}$

The first official agreement between states was made in the Justice and Home Affairs Council meeting on $20^{\text {th }}$ of July, where the ministers agreed on the contribution by each Member State to the relocation and resettlement program. The agreement was made on the relocation scheme for 32256 persons with an aim to continue the discussions of the remaining people. An agreement on the resettlement scheme was also made and the number of people rose from to 22504 people. $^{38}$

Almost four months after the Commission's first package of proposals, a second package, issued on $9^{\text {th }}$ of September 2015 was delivered to the Member States. The second package included an emergency relocation proposal for 120000 people from frontline countries; a permanent relocation mechanism for all Member States; a common European list of safe countries of origin; a more effective return policy; measures to address the external dimension of the refugee crisis and a trust fund for Africa. ${ }^{39}$

In comparison to the first package, the main differences were the additional 120 000 people that needed to be relocated and the fact that Hungary was added into the list of frontline countries. The relocation scheme was created in order to relocate 15600 people from Italy, 50400 from Greece and 5400 from Hungary. The distribution key remained the same. But due to the increase of people, the Member States were promised additional 780 million EUR for participating in the program. In addition the nationalities that would be relocated were not only Syrian and Eritrean but Iraqis were also added to the list. ${ }^{40}$

A new approach was also introduced in the second package of proposals, the temporary solidarity clause. If - for justified and objective reasons such as a natural disaster - a Member State cannot temporarily participate totally or in part in a relocation decision, it will have to make a financial contribution to the EU budget of an amount of $0.002 \%$ of its GDP. ${ }^{41}$

This is a mechanism that does not justify any reasons, not even force majored ones, not to participate in the relocation scheme unless you have become one of the frontline countries.

\footnotetext{
${ }^{36}$ UNHCR sub regional operations profile 2015 Northern, Western, Central and Southern Europe.

${ }^{37}$ European Commission makes progress on Agenda on Migration.

${ }^{38}$ Justice and Home Affairs Council 20/07/2015.

${ }^{39}$ Refugee Crisis: European Commission takes decisive action.

${ }^{40}$ Ibid

${ }^{41}$ Ibid
} 
The concept of a permanent relocation mechanism for all Member States was also specified in the second package of proposals: Commission is proposing a structured solidarity mechanism which can be triggered any time to help any EUMember State experiencing a crisis situation and extreme pressure on its asylum system. The same objective and verifiable distribution criteria would apply as in the emergency relocation proposals. ${ }^{42}$

Two weeks after the Commission's second proposal package, another Justice and Home Affairs Council gathered on $22^{\text {nd }}$ of September 2015. They reached an agreement on 66000 people from Italy and Greece, leaving Hungary out, because they voted against the relocation scheme in general. ${ }^{43}$ Surprisingly no alterations were made compared to the Commissions second action plan proposals.

A third package of proposals was launched in December 2015 that was aimed at securing the EU's external borders and managing the flows of migration more efficiently. The Commission proposed to establish a European Border and Coast Guard to ensure a strong and shared management of the external borders. ${ }^{44}$

This was the first time that the EU opted to take specific actions against the problems of the Union's external borders; previously the Union had chosen to focus more on the people that had already arrived and to the prevention of indicating a focus shift.

In February 2016 The Council adopted a recommendation on addressing serious deficiencies identified during an evaluation of Greece's application of the Schengen acquis in the area of external border management. ${ }^{45}$

This action is again worth being noted because it is the first time, since the crisis started, that the Union publicly acknowledged the responsibility of certain border state's involvement of the escalation of this crisis, meaning that they have not been able to secure their borders and have thereby not entirely fulfilled their international obligations.

In March 2016, the Council's Permanent Representatives Committee agreed on an emergency support mechanism in response to the difficult humanitarian situation caused by the refugee crisis notably in Greece. This enables the EU to help Greece and other affected member states to address the humanitarian needs of the large numbers of arrivals. The EU's humanitarian assistance is aimed at meeting the basic needs of refugees by providing food, shelter, water, medicine and other necessities. The Commission estimates that a total of $€ 700$ million will be needed in 2016-2018 to address the needs of refugees, of which $€ 300$ million will be required in 2016 . ${ }^{46}$ This measure is created in order to help tackle the economical inequalities that the current Dublin system deteriorates and thereby offering compensation (help) to the Border States for the unequal burden sharing of refugee flows.

In the Press release of European Commission from 9th November 2016 Commission calls Member States to sustain efforts to deliver their commitments on

\footnotetext{
${ }^{42}$ Ibid

43 Justice and Home Affairs Council 22/09/2015.

${ }^{44}$ A European Border and Coast Guard to protect Europe's External Borders.

45 Schengen evaluation of Greece: Council adopts recommendation to address deficiencies in external borders.

${ }^{46}$ Refugee crisis: Council shows solidarity with Greece by approving emergency support.
} 
relocation and resettlement. The press release is highlighting the problem in a following way:

"After the record 1,372 transfers which took place in September, October proved to be a transitional month with a slower pace of relocation than during previous reporting periods. From 28 September until 8 November, 1212 people were relocated, with 921 from Greece and 291 from Italy. The lower number of transfers in October (779, of which 549 from Greece and 230 from Italy) reflects in particular the low number of pledges made during the month of August, which has had a knock on effect in terms of lower transfer rates."

It shows clearly that the political objectives are very difficult to put in practice as we are talking about the people we are relocating. For each of them we have to find personal solutions to find housing, work and provide other support for better integration into new society. Besides most of these persons we are dealing with have traumatic life experiences and different cultural background and expectations.

\section{Conclusion}

The empirical overview of the European migration crisis exhibited that the main reasons behind the EU's failure are the contradictions inside the Common Asylum System itself, the incomplete nature of the EU's integration and the different interests of Member States. Even though the crisis has now lasted for years, the EU has still not been able to alleviate the situation, furthermore there are signs of different interest groups that cooperate with each other in order to gain more impact and who do not follow the Union's prescribed action plans. Even though the EU is very disjointed the method of securitization has never been used in order to take extraordinary measures. The role of the courts is important to give new guidelines for the further developments of the protection of persons seeking asylum but also the directions how EU should shape its policies bearing in mind the human rights and its own obligations written down in the Treaties and agree upon between Member States. Burden sharing imposed by the EU to the member states has created conflict and satisfaction of the ability of EU to resolve the problems. It seems that there should be more dialogs introduced between different parties, the states, the beneficiaries and the EU. Resolving crisis situation needs quick response and consensus which is extremely difficult in the situation when there are 28 different countries with their own immigration policies and rules. Role of the CJEU and ECrtHR has increased in resolving the legal difficulties to apply the EU migration law and the harmonization of it application. Member States of EU who are not happy with the political decisions taken at the Council and Commission level also turn to the courts to get answers on the legality of these decisions shows a clear need for better cooperation and maybe to go back to the unanimous voting system and decision making process in the fields where the member states are directly responsible for the persons arriving to their territory. Failure of relocation actions is evident from the small numbers that EU member states have.

Migration and migration flows of forced migrants, has always been something that states have not been able to stop. Refusing asylum seekers or other forced migrants at the borders will lead only to more violations of human rights. Therefor in order to manage the arrival and reception of the persons arriving to EU, the 
procedures have to be made more quick and manageable and less bureaucratic. Also new technological developments can be used to enhance the identification, registration and relocation of persons within EU. When data is inserted to the information system the programs can start to make decisions on the relocation and asylum application. Using more technological solutions in the migration management can also reduce costs that currently are associated with the asylum seekers and forced migration control.

\section{References}

European Agenda on Migration. (2015). European Commission. (Official action plan). http://ec.europa.eu/dgs/home-affairs/what-we-do/policies/european-agenda-migra tion/background-information/docs/communication_on_the_european_agenda_on _migra tion_en.pdf

A European Border and Coast Guard to protect Europe's External Borders. (2015). European Commission. (Press release of 15. December, 2015) http://europa.eu/ rapid/pressrelease_IP-15-6327_en.htm?locale=EN

About the Visegrad Group. Visegrad Group. www.visegradgorup.eu

Achiron, M. (2001). 'The Geneva Convention has been the cornerstone of protection for 50 years, but there is a lively debate about its relevance today' in Refugees. Vol 123: 4-8.

Asylum Statistics. Eurostat. http://ec.europa.eu/eurostat/statistics-explained/index.php/ Asylum_statistics\#Asylum_applicants.

Bagdonas, A. (2015). 'The EU Migration Crisis and the Baltic Security' in Journal on Baltic Security. Vol 1(2): 7-28.

Boswell, C. (2000). 'European values and the asylum crisis' in International Affairs. Vol. 76(3): 537-557.

Charter of the United Nations. http://www.un.org/en/sections/un-charter/preamble/in dex.html

Clayton, G. (2011). 'Asylum Seekers in Europe: M.S.S. v Belgium and Greece' in Human Rights Law Review. Vol. 11(4): 758-773.

Common European Asylum System. European Commission. http://ec.europa.eu/dgs/ homeaffairs/what-we-do/policies/asylum/index_en.htm

ECtHR - M.S.S. v Belgium and Greece [GC], Application No. 30696/09

ECtHR - K.R.S. v the United Kingdom, Application no. 32733/08 (decision on admissibility), 2 December 2008

European Commission - Fact Sheet First measures under the European Agenda on Migration: Questions and Answers. European Commission. (2015). (Press release) http://europa.eu/rapid/press-release_MEMO-15-5038_en.htm

European Commission makes progress on Agenda on Migration. European Commission. (2015). (Press release) http://europa.eu/rapid/press-release_IP-15-5039_en.htm European Commission. (Annexes of the official proposal) http://ec. europa.eu/dgs/home-affairs/e-library/documents/policies/asylum/general/docs/pro posal_for_a_council_decision_on_provisional_relocation_measures_for_italy_and_gre ece_annex_en.pdf

European Council Conclusions. http://www.consilium.europa.eu/en/press/press-relea ses/2016/02/19-euco-conclusions

Finding solutions to migratory pressures. Council of the European Union. http://www. consilium.europa.eu/en/policies/migratory-pressures

Informal meeting of EU heads of state or government on migration, 23rd of September 2015 statement. http://www.consilium.europa.eu/en/press/press-releases/2015/09 /23statement-informal-meeting 
Joint Framework on Countering Hybrid Threats. European Commission. (Press release). http://europa.eu/rapid/press-release_MEMO-16-1250_en.htm

Joint Statement on Migration. Visegrad Group. http://www.visegradgroup.eu/calen dar/2016/joint-statement-on

Judgment of the Court (Grand Chamber) of 21 December 2011. N. S. (C-411/10) v Secretary of State for the Home Department and M. E. and Others (C-493/10) v Refugee Applications Commissioner and Minister for Justice, Equality and Law Reform

Justice and Home Affairs Council 20/07/2015. Council of the European Union. http://www.consilium.europa.eu/en/meetings/jha/2015/07/20

Justice and Home Affairs Council 22/09/2015. Council of the European Union. http://www.consilium.europa.eu/en/meetings/jha/2015/09/22

Key Migration Terms (2015). International Organisation for Migration. https://www. iom.int/key-migration-terms

Langford, L.M. (2013). 'The Other Euro Crisis: Rights Violations Under the Common European Asylum System and the Unraveling of EU Solidarity' in Harvard Human Rights Journal. Vol. 26(1): 17-264.

Mallia, P. (2011). 'Case of M.S.S. v. Belgium and Greece: A Catalyst in the Re-Thinking of the Dublin II Regulation", in Refugee Survey Quarterly.Vol. 30(3): 107-128.

Refugee crisis: Council shows solidarity with Greece by approving emergency support. (2016).

Council of the European Union. (Press release). http://www.consilium.europa.eu/en/ press/press-releases/2016/03/09-refugee-crisis/

Refugee Crisis: European Commission takes decisive action. (2015). European Commission. (Press release) http://europa.eu/rapid/press-release_IP-15-5596_en.htm

Schengen evaluation of Greece: Council adopts recommendation to address deficiencies in external borders. (2016). Council of the European Union. (Press release) http://www.consilium.europa.eu/en/press/press-releases/2016/02/12-sche ngenevaluation-of-greece

Special Meeting of the European Council 23/04/2015. Council of the European Union.

States Parties to the 1951 Convention relating to the Status of Refugees and the 1967 Protocol. United Nations High Commissioner for Refugees. http://www.unhcr. org/protect/PROTECTION/3b73b0d63.pdf

Syrian Refugees. Migration Policy Centre of the European University Institute. http:// syrianrefugees.eu/?page_id=10

The 1951 Geneva Convention relating to the status of Refugees and it's 1967 NY protocol.

United Nations High Commissioner for Refugees. http://www.unhcr.org/pages/49da0 e466.html

The Dublin System. European Commission. http://ec.europa.eu/dgs/home-affairs/ what-wedo/policies/european-agenda-migration/background-

information/docs/20160406/factsheet_-_the_dublin_system_en.pdf (10.11.2016)

The Migration wave cannot be contained without the border fence. Hungarian Government. http://www.kormany.hu/en/news/the-migration-wave-cannot-be-contained-witho utthe-border-fence

UNHCR sub regional operations profile 2015 Northern, Western, Central and Southern Europe. United Nations High Commissioner of Refugees. http://www.unhcr.org/ pages/49e48e5f6.html

Universal Declaration of Human Rights. http://www.un.org/en/universal-declaration-humanrights 